\title{
OVER DE VOORTPLANTING DER TARDIGRADEN
}

\author{
DOOR \\ J. C. C. LOMAN. \\ (Met een figuur in den tekst)
}

Oorspronkelijk heeft men onder de Tardigraden zeker mannelijke en vrouwelijke dieren meenen te herkennen. In de beschrijving toch, die O. F. MüLLER van hen geeft, komt het volgende voor: "Auch habe ich junge und ältere, kleinere und grössere, oder Männchen und Weibchen angetroffen," en eenige regels te voren beschrijft hij het verschil tusschen beide geslachten, en acht het waarschijnlijk „dass jene mit den kleinkörnigten Flecken Männchen, die mit den hellern Kugeln unbefruchteten, und mit den dunklen befruchtete Weibgen sind." In die meening heeft men verkeerd tot 1840, toen DoYĖRE, in zijn beroemde verhandeling over de Tardigraden, aantoonde, dat in hetzelfde individu zoowel ovariën als testes werden aangetroffen, en dat wij dus met tweeslachtige dieren te doen hadden. De eerstvolgende onderzoekers twijfelen dan ook niet aan de hermaphrodiete natuur dezer wezens. Maar in 1889 heeft PLATE de eerste beschrijving gegeven van de ware mannetjes, die evenwel zeer zeldzaam schijnen te zijn, en daar deze ontdekking sindsdien door alle autoren bevestigd is geworden, mogen wij thans wel met zekerheid aannemen, dat DOYĖRE zich vergist heeft. Van Februari tot Mei kan men evenveel mannetjes verzamelen als wijfjes, doch de helft kleiner, zegt v. ERLANGER, en dit wordt later door HENNEKE bevestigd. VON WENCK vindt mannetjes in alle jaargetijden, BAUMANN daarentegen slechts van November tot Februari, en dan bovendien zeldzaam (50 우 op $\left.10^{7}\right)$. Overeenstemming der meeningen heerscht hier dus nog niet.

HENNEKE heeft ook de copulatie beschreven. Een wijfje werd door eenige mannetjes omringd, die zich aan haar vastklemden. Vervolgens trok het dier zich samen en de oude huid ging als een zak los zitten, waarop de mannetjes met de tandjes die huid aanboren en hun sperma in dezen zak uitstorten, die aan het achterlijf van het wijfje bevestigd blijft. Terstond daarna begint het eierleggen. HENNEKE zag, dat wel 15 eieren in 5 minuten in den zak gelegd werden, waar de bevruchting door de rondzwermende spermatozoën moet geschieden. De zak met bevruchte eieren wordt door de wijfjes langen tijd meegesleept, totdat de eieren uitgekomen zijn. Bij andere soorten evenwel laten de wijfjes den met eieren gevulden zak los en bemoeien zich verder niet met hun kroost. Soms vindt men intusschen eieren wier harde schaal met talrijke uitwassen of stekels bezet is en die meest alleen, of als klissen vereenigd; in de omgeving der diertjes worden aangetroffen. Volgens de gangbare meening behooren zulke eieren weder aan andere soorten toe, maar in den laatsten tijd ben ik dit gaan betwijfelen en acht ik de mogelijkheid niet uitgesloten, dat eenzelfde soort onder verschillende omstandigheden ook verschillende eieren legt.

Gedurende ongeveer een jaar achtereen onderzocht ik den inhoud van een moszode, uit Bergen (N. H.) afkomstig, door een zeer talrijke kolonie van Macrobiotus Oberhäuser bevolkt. Deze Tardigrade was de eenigste, die ik daarin ooit heb aangetroffen, hetgeen lang niet altijd voorkomt; veelal leven meer soorten in eenzelfde mos bijeen. Aanvankelijk trof $\mathrm{ik} \mathrm{nu}$, behalve jongere dieren in levendigen groei, ook eieren en eierschalen van deze soort (Fig. A), wier vorm volkomen aan de oorspronkelijke beschrijving van DoYÈRE beantwoordde: „Les œufs, incolores, sont sphériques, d'un diametre d'environ 
0,06 mm.; leur enveloppe est couverte de mamelons gros, courts et obtus, qui leur donnent exactement l'aspect d'une framboise." Doch gedurende de wintermaanden had een sterke voortplanting plaats; tal van ledige huiden trof $\mathrm{ik}$ aan, gevuld met eieren in alle stadiën van ontwikkeling, van de eerste klieving af, tot aan het uitkomen der jongen, dat ik ook bij deze soort onder het mikroskoop heb waargenomen. Het aantal eieren door een wijfje gelegd is steeds gering, meest twee (Fig. B), zelden meer, en slechts éénmaal vond ik een legsel van vijf. In al deze gevallen hebben die eieren een dunne huid, zonder uitwassen; zijn ook niet bolrond, maar een weinig ellipsoïde.

Hier hebben wij dus een Tardigrade (Macrobiotus
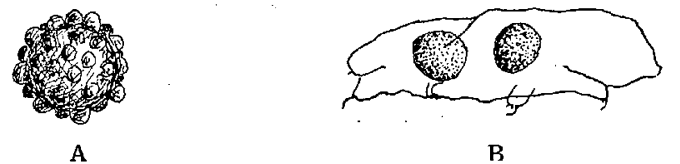

Fig. A. Ei van Macrobiotus Oberhäuser Doy. met harde schaal.

Fig. B. Eieren van Macrobiotus Oberhäuser Doy. met gladde eischaal, in de afgestroopte huid gelegd. Oberhäuser Doy.), die tweeërlei vormen van eieren bezit. Wel heb ik het uitkomen der oorspronkelijke dieren in September 1919 uit de harde, knobbelige schaal niet gezien; toch kan ik niet twijfelen of dat heeft plaats gevonden, want niet alleen DOYĖRE, gelijk wij hierboven zagen, maar later ook GREEFF en ThuLIN vermelden hetzelfde. GREefF zegt van de eieren dezer soort: „Die Eier sind kugelig und haben ca. 0,06 mm. im Durchmesser. Die äussere Schale

ist dicht bedeckt mit feinen, nicht starren Stacheln." En THuLIN deelt ervan mede: „Die Eier sind klein und haben an ihrer Oberfläche eine grössere oder kleinere Anzahl Ausschüsse. Diese sind oft von verschiedener Form und Grösse. Die meisten sind halbkugelförmig, andere zugespitzt oder unregelmässig abgestumpft, andere wieder erinnern ihrer Form nach an Stundengläser., Die Eier werden frei abgelegt. Nur einmal habe ich 5 Eier beobachtet, die in der abgezogenen Cuticula gelegt worden waren."

Het is een gelukkige omstandigheid, dat Macrobiotus Oberhäuser haast de gemakkelijkst herkenbare soort genoemd mag worden, wat van andere Tardigraden-species volstrekt niet altijd te zeggen valt. Er zijn daaronder, die dikwijls elkaar begeleiden, veel op elkaar gelijken, en waarvan de eene soms hare eieren in de leege huid legt, terwijl bij de andere hardschalige eieren met allerlei uitgroeisels gevonden zijn.

Dit geeft te denken. Te meer daar RichTERs, een der beste Tardigraden-kenners, gelooft, dat DOYĖE en anderen zich vergist hebben, waar zij aan de soort in kwestie eieren met een ruwe schaal toekennen. Immers hij verklaart uitdrukkelijk het tegengestelde: „Macrobiotus Oberhäuser ist, nach meinen Beobachtungen, keine Art, die frei ablegt, sondern Gelege in Hautsäcken erzeugt." En dan eenige regels verder: „Die Gelege enthalten 2 oder 4 Eier."

Deze mededeeling kan slechts een voorloopige zijn. Elke vraag uit het leven onzer dieren, die door waarneming opgelost wordt, brengt terstond andere naar voren. Als het, na het voorafgaande, waarschijnlijk wordt, dat Macrobiotus twee vormen van eieren heeft; kan dit samenhangen met de tijdelijke uitdroging, waaraan mosbewoners herhaaldelijk blootstaan en waaraan zij, zooals bekend is, ook gemakkelijk weerstand kunnen bieden. Alleen bij voldoende vochtigheid vindt een sterke vermenigvuldiging plaats door dunschalige eieren met kortstondigen ontwikkelingsduur. De dikwandige, stekelige eieren zijn dan bestemd om gedurende het ongunstige jaargetijde de soort in het leven te houden, afgezien van het vermogen der dieren zelf om dorre droogte of hevige koude te trotseeren. Van soorten, die altijd in het water leven, zooals b.v. Macrobiotus macronyx, kent men geen hardschalige eieren.

En wat nu ten slotte het voorkomen van mannetjes aangaat, bij Macrobiotus Oberhäuser heb ik hen, gedurende de snelle voortplanting in den winter, nooit kunnen waarnemen. Wellicht dat, in deze levensperiode althans, bij Tardigraden dus een parthenogenetische generatie voorkomt (Thelytokie), en dat slechts onder bepaalde omstandigheden mannetjes optreden. Bij echte zoetwatervormen schijnen mannetjes het geheele jaar door te worden aangetroffen. Bij de gewone Macrobiotus Hufelandii daarentegen heeft onlangs BAUMANN een receptaculum seminis beschreven, en vindt de zeer zeldzaam verschijnende mannetjes van November tot Februari. Waar nog zoo weinig houvast aan de feiten bestaat, zou het derhalve zeer voorbarig wezen om nu reeds gevolgtrekkingen van algemeenen aard te willen maken. 


\section{TITELS.}

Baumánn, Beitrag zur Kenntnis der Anatomie der Tardigraden, in: Zeitschr. f. wiss. Zool., 118, 1921, p. 637.

DOYĖRE, Mémoire sur les Tardigrades, in: Ann. Sc. nat. (2), 14, 1840.

v. ERLANGer, Zur Morphologie und Biologie eines Tardigraden II, in: Biol. Zentralbl., 15, 1895, p. 772.

GREEFF, Untersuchungen über den Bau und die Naturgeschichte der Bärthierchen, in: Archiv f. mikr. Anat. 2, 1866, p. 102.

HENNEKE, Breiträge zur Kenntnis der Biologie und Anatomie der Tardigraden, in: Zeitschr. f. wiss. Zool. 97, 1910-11, p. 721.

O. F. MÜlLER, Von den Bärthierchen, in: Archiv der Insectengeschichte von J. C. Fuessly, 1785, 6. Heft, p. 27.

Plate, Beiträge zur Naturgeschichte der Tardigraden, in: Zool. Jahrb. Anat. Ont. 3, 1889, p. 487.

RichteRs, Die Eier der Tardigraden, in: Ber. Senckenberg Naturf. Ges. 1904, p. 64.

Thulin, Tardigradenfauna Schwedens, in: Arkiv f. Zoologi, 1911, Abh. 16, p. 35.

v. WENCK, Entwicklungsgeschichtliche Untersuchungen an Tardigraden, in: Zool. Jahrb. Anat. Ont. 37, 1914, p. 465. 